\title{
Energy secretary ditches science advisers
}

\section{WASHINGTONDC}

The US Secretary of Energy, Samuel Bodman, has decided to disband the Department of Energy's principal independent advisory board on scientific and technical matters.

The Secretary of Energy Advisory Board (SEAB), which has existed in one form or another since 1978 , will end after a final meeting this spring. Bodman made the decision about a month ago in a closed-door meeting with senior staff, says department spokesman Craig Stevens.

Some observers say that the decision is another example of the Bush administration's reluctance to accept outside scientific advice (see page 716). "This decision is part of a bigger picture," says Stephen Dean, president of Fusion Power Associates, a non-profit organization based in Gaithersburg, Maryland, that promotes fusion research. "This administration doesn't want outside advisory groups to tell it what to do."

But Stevens says that the choice has more to do with the scientificbackground of Bodman, who is a chemical engineer by training, than a desire to limit scientific advice. ${ }^{\alpha}$ The secretary has an understanding of science and scientific processes," Stevens says. "He would rather hear firsthand from the folks in the department." Stevens adds that plenty of direction is provided by the Advanced Energy and American Competitiveness Initiatives, which are intended to boost work on energy and basic research.

The 28-member, politically appointed SEAB

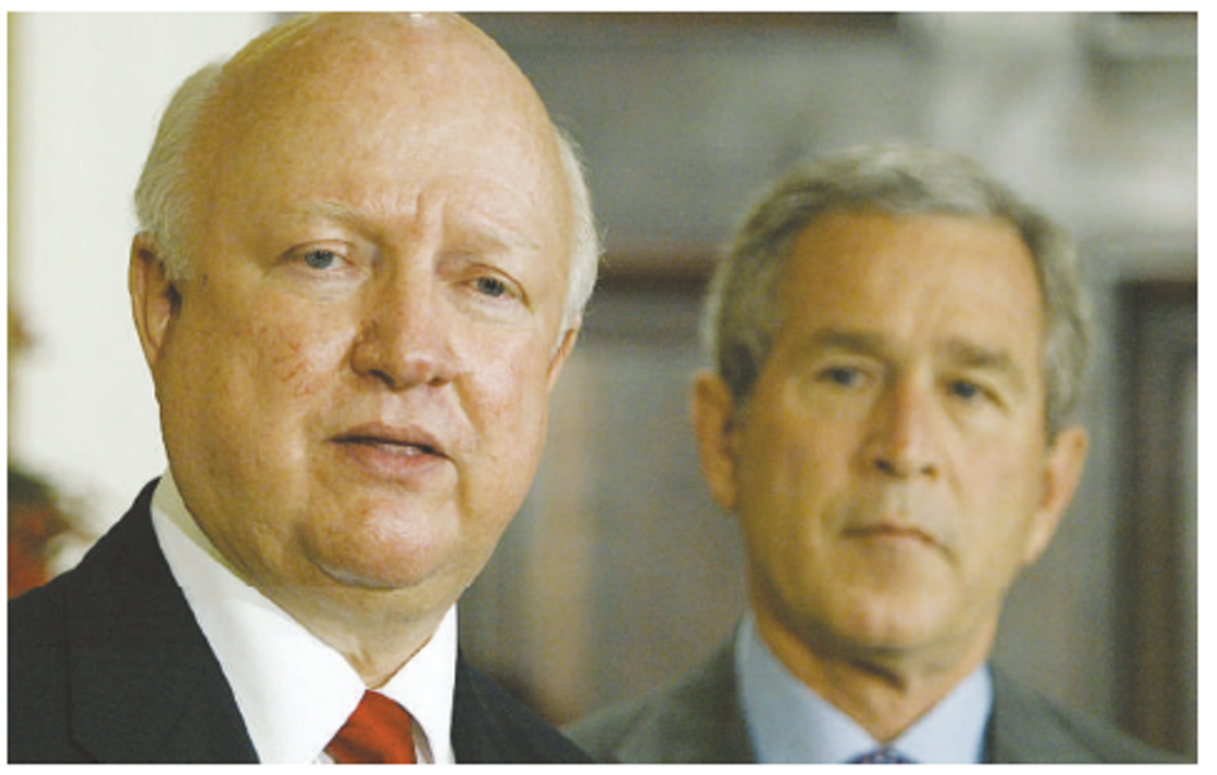

Stand alone: President Bush's energy depar tment is headed by chemical engineer Samuel Bodman (left).

is a mix of distinguished scientists, such as Nobel laureate Burton Richter, and business executives, such as former ExxonMobil chairman Lee Raymond. But not all of its reports have been influential, says Mark Marin, a lobbyist with Lewis-Burke Associates in Washington DC. One recent report, on research funding in the department, was incorporated into the president's competitiveness initiative, but a study on laboratory contracting practices was largely ignored.

The panel's most recent report, in July 2005, recommended drastic restructuring of the nation's nuclear-weapons labs (see Nature 436, $316 ; 2005)$. The study riled some in Congress, but Stevens denies that this had any influence on the decision to dissolve the board.

The SEAB was not the only group to give scientific advice to the secretary; several boards regularly report on issues such as nuclear physics and energy research. Richter, of the Stanford Linear Accelerator Center in Menlo Park, California, says that Bodman can consult whomever he wishes: ${ }^{\alpha}$ The secretary will get his advice where he wants to get his advice." Geoff Brumfiel

\section{Wellcome Trust fuelled bid to save British science treasure}

The Wellcome Trust putits financial weight behind Britain's Royal Society last week in order to rescue a prized seventeenth-century manuscript from bidders at Bonhams auction house in London.

The society claims that the 520 page treasure, handwritten by the physicist Robert Hooke, was taken from its archives some 300 years ago, and put outa public plea to recover the papers (see Nature 439,638-639;2006). The privately funded Wellcome Trust pledged half of the $\{1$ million (US\$1.7 million) that the society used to negotiate an eleventh-hour deal with the manuscript's vendors.

The papers document the society's meetings from 1661 to 1682 , and feature many personal comments from Hooke, former secretary of the society and one of its most influentials scientists. The manuscript was found in a private house in Hampshire last year. When it became ap parent in February that the papers were to be auctioned off, the society appealed for benefactors.

The resulting $\mathrm{E} 1$ million came from 146 separate pledges, 122 of which were from Royal Society fellows. Donations ranged from $£ 5$ to $£ 500,000$, although a society spokesmantold Nature that the Wellcome Trust was not the only substantialdonor.

"We are very grateful," says the Royal Society's president, Martin Rees. "We're delighted because the manus cript has gone to its natural place." The society hopes to take delivery of the document this month, and is planning to display it as part of a summer exhibition at the society's London headquarters. Historians will scrutinize the handwritten papers for discrepancies with the formal minutes of the meetings, which the society already has. The results may resolve several disputes, such as Hooke's claim that he was the original inventor of the springbalance watch.

Clare Matterson, director of medicine, society and history at Wellcome, says the manuscript is "equivalent toa Shakespeare folio". Michael Hopkin 